\title{
KAWASAN CIGONDEWAH TERKAIT SARANA PRASARANA LINGKUNGAN TERBANGUN SEBAGAI KAWASAN WISATA TEKSTIL DI KOTA BANDUNG
}

\section{Karto Wijaya}

Program Studi Arsitektur, Universitas Kebangsaan

kartowijaya@universitaskebangsaan.ac.id

\author{
Asep Yudi Permana \\ Program Studi Teknik Arsitektur, FPTK UPI \\ asepyudipermana@upi.edu
}

\begin{abstract}
Abstrak
Kawasan Cigondewah pada awalnya merupakan kawasan agraris, dan kawasan ini mengalami perkembangan kearah sentra perdagangan kain dan industri tekstil sejak tahun 1960-1976 yang ditandai oleh usaha karung goni oleh masyarakat setempat. Kegiatan ekonomi berbasis home industri ini memberikan kontribusi pendapatan bagi khususnya penduduk setempat, karena tenaga kerja berasal dari sekitar kelurahan Cigondewah sendiri. Mulanya usaha karung goni ini dibeli dari pabrik gula yang kemudian dipasarkan hingga Kawarang dan Banten. Pada tahun 1976 mengalami kejenuhan, yang kemudian masyarakat setempat beralih dari usaha karung goni ke imbah industri (karung plastik dan kain bekas). Pada awal 1997 kawasan cigondewah mampu berperan sebagai sentra perdagangan kain. Sentra ini melayani pembeli-pembeli yang berasal dari Bandung dan sekitasrnya. Bahan baku dari tekstil berasal dari pabrik yang ada di wilayah tersebut, namun sebagian lagi berasal dari Jakarta melalui pelabuhan Tanjung Priok. Kawasan ini dalam RTRW Kota Bandung adalah kawasan industri berwawasan lingkungan. Perkembangan kawasan ini memberikan potensi yang luas terutama dalam pengembangannya sebagai sebuah kawasan yang memiliki produk unggulan/spesialisasi dalam cakupan rencana pengembangan pariwisata Kota Bandung. Penelitian ini merupakan studi penelitian deskriptif dengan menggunakan pendekatan kualitatif, di mana melalui pendekatan ini bertujuan untuk memberikan gambaran mengenai fakta dan fenomena yang terjadi dilapangan. Berdasarkan hasil analisis penelitian ditemukan potensi dan karakteristik kawasan yang mendukung dalam pengembangan Kawasan Cigondewah sebagai Kawasan Wisata Tesktil di Kota Bandung. Terkait dengan prasarana dan sarana lingkungan ditemukan permasalahan, antara lain: ketersediaan sarana parkir dan jalur pedestrian yang kurang memadai, kondisi kawasan yang belum tertata secara maksimal.
\end{abstract}

Kata-kata Kunci: Lingkungan Terbangun, Perkembangan Kawasan 


\title{
CIGONDEWAH AREA RELATED TO ENVIRONMENT BUILT INFRASTRUCTURE FACILITIES AS SENTRA CLOTH IN BANDUNG CITY
}

\begin{abstract}
The Cigondewah area was originally an agrarian area, and the region has been progressing towards the trading center of textile fabrics and industry since 1960-1976 which is marked by the burlap sack by the local community. This home industry-based economic activity contributes the income to the locals in particular, since the labor comes from around Cigondewah urban village itself. Initially, this sack business was purchased from a sugar factory which was then marketed to Kawarang and Banten. In 1976 experienced saturation, which then the local community shifted from the business of burlap sack to industrial waste (plastic bags and used cloth). In early 1997 the cigondewah area was able to serve as a fabric trading center. This center serves buyers who come from Bandung and sekitasrnya. Textile raw materials come from existing factories in the area, but some come from Jakarta through the port of Tanjung Priok. This area in RTRW Bandung is environmentally friendly industrial area. The development of this area provides a wide potential especially in its development as an area that has excellent products / specialization in coverage of tourism development plan of Bandung City. This research is a descriptive research study using a qualitative approach, which through this approach aims to provide an overview of the facts and phenomena that occur in the field. Based on the results of research analysis found the potential and characteristics of the area that supports the development of Cigondewah Area as Tourism Area Tesktil in Bandung. Related to infrastructure and environmental facilities found problems, among others: the availability of parking facilities and pedestrian paths are inadequate, the condition of the area that has not been set up optimally.
\end{abstract}

Keywords: Built Environment, Regional Development

\section{Pendahuluan}

Kawasan Cigondewah merupakan kawasan pemukiman yang disulap menjadi sentra penjualan kain. Mayoritas penggunaan kawasan ini diantaranya pedagang dan pengusaha yang sebagian besar merupakan penghuni sebagai pelaku ekonomi utama. Sebagian besar penduduk yang tinggal di wilayah Cigondewah berpotensi sebagai penjual kain, ratusan toko yang berjejer di sepanjang jalan wilayah Cigondewah menjajakan kain (Wijaya, Setioko, \& Murtini, 2015).

Kawasan Wisata Belanja kain ini terletak pada kelurahan Cigondewah Rahayu, Kecamatan Bojongloa Kaler Kota Bandung, namun kawasan tekstil itu sendiri mencakup wilayah yang terdiri dari tiga desa yang berbeda yaitu Cigondewah Rahayu, Cigondewah Kaler dan Cigondewah Kidul pada kecamatan Bandung kulon, bahkan ada beberapa bagian wilayah sentra tekstil ini yang berada pada wilayah Kabupaten Bandung. Kawasan ini dalam dokumen perencanaan pemerintah Kota Bandung direncanakan untuk dikembangkan sebagai kawasan wisata belanja kain di Kota Bandung. Berdekatan dengan Pusat Sekunder Kopo Kencana yang ditetapkan sebagai pusat dari inti kota untuk melayani daerah dalam Wilayah Pembangunan Tegalega. Kawasan ini dalam RTRW Kota Bandung adalah kawasan industri berwawasan lingkungan dan sebagian menempati kawasan perumahan. Oleh karena itu menurut Sudjarto (1985) kemampuan suatu jenis kegiatan menempatkan diri pada lokasi yang strategis tergantung kepada tingkat produktivitas yang dimiliki kegiatan tersebut. Kegiatankegiatan yang memiliki tingkat produktivitas tinggi adalah kegiatan komersial dan industri, jadi kedua jenis kegiatan tersebut mempunyai potensi yang besar untuk melakukan konservasi kegiatan di suatu lahan.

Berdasarkan latar belakang yang telah diuraikan maka dapat di rumuskan permasalahannya yaitu:(1) Bagaimana potensi dan karakteristik Kawasan Cigondewah sebagai kawasan Wisata Tekstil 
di Kota Bandung? (2) Permaslahan prasarana dan sarana lingkungan apa saja yang mempengaruhi perkembangan kawasan Cigondewah sebagai kawasan Wisata Tekstil di Kota Bandung?

\section{Kajian Pustaka}

Menurut Sugandhy (1999) Pengelolaan Lingkungan hidup adalah upaya sadar dan berencana secara terpadu dalam pemanfaatan, penataan, pemeliharaan, pengawasan, pengendalian dan pengembangan sumberdaya secara bijaksana untuk meningkatkan mutu lingkungan hidup. Tujuan pengelolaan lingkungan hidup di Indonesia adalah untuk (a) tercapainya keselarasan hubungan antara manusia dengan lingkungan hidup sebagai tujuan membangun manusia Indonesia seutuhnya; (b) terkendalinya pemanfaatan sumberdaya secara bijaksana; (c) terwujudnya manusia Indonesia sebagai Pembina lingkungan hidup; (d) terlaksananya pembangunan berwawasan lingkungan untuk kepentingan generasi sekarang dan mendatang; dan (e) terlindungnya Negara terhadap dampak kegiatan di luar wilayah Negara yang menyebabkan kerusakan dan pencemaran lingkungan.

Selanjutnya Hadi (2001) mengemukaan bahwa dampak sosial muncul ketika terdapat aktivitas: proyek, program atau kebijaksanaan yang akan ditetapkan pada suatu masyarakat. Bentuk intervensi ini mempengaruhi keseimbangan pada suatu system (masyarakat). Pengaruh ini bisa positif, bisa pula negatif.

\section{Kawasan Wisata \\ Pariwisata dan Kawasan Wisata}

Selama empat dasawarsa pembangunan nasional, kebijakan kepariwisataan telah mengalami perubahan yang signifikan. Awalnya, pariwisata dipandang sebagai kegiatan pembangunan yang berbasiskan kebudayaan, kemudian sebagai salah satu andalan sektor ekonomi terutama bagi peningkatan penerimaan devisa (Jaya, 2007). Hal ini juga ditetapkan Menurut Undang-undang No. 9 tahun 1990, pariwisata adalah segala sesuatu yang berhubungan dengan wisata, termasuk pengusahaan objek dan daya tarik wisata serta usaha-usaha yang terkait di bidang tersebut. Sedangkan kawasan wisata adalah kawasan yang secara teknis digunakan untuk kegiatan pariwisata yang ramah lingkungan dengan batasan-batasan tertentu.

Di dalam kawasan wisata dibangun objek dan daya tarik wisata serta prasarana dan sarana pariwisata. Kawasan wisata tidak perlu diartikan sebagai suatu kawasan yang bersifat khusus dalam arti eksklusif, apalagi bersifat tertutup. Kawasan serupa itu harus tetap merupakan kawasan yang sifatnya terbuka, yang tujuannya adalah mengembangkan suatu kawasan sebagai tujuan wisata.

\section{Tujuan Kawasan Wisata untuk mewadahi Masyarakat}

Tujuan-tujuan masyarakat hendaknya dapat diwadahi dalam kegiatan pariwisata agar kondisi yang harmonis antara pengunjung/wisatawan, tempat dan masyarakat setempat dapat terwujud. Misalnya, kerja sama dalam wisata budaya atau cultural tourism partnership dapat dilakukan mulai dari tahap perencanaan, manajemen, sampai pada pemasaran.

Menurut Jaya (2007) dalam pengembangan pariwisata ada 3 faktor yang perlu dipertimbangkan, yaitu:

1. Faktor ekonomi, antara lain:(a) Tingkat pertumbuhan yang positif dari disposible income;(b) Tingkat pertumbuhan produk domistik regional bruto yang dapat diukurdari berbagai aktivitas ekonomi dan pendapatan riil; (c) Perkembangan teknologi dan industri sehingga lebih banyak waktu pekerja yang digunakan untuk rekreasi dan menganggur; (d) Biaya transportasi yang relatif murah; (e) Tersedianya perbaikan dan kemajuan infrastruktur, sehingga tersedia berbagai fasilitas yang dapat menjangkau wisata; dan (f) Dalam jangka panjang konsekuensi pertumbuhan ekonomi akan mempengaruhi perkembangan kepariwisataan. 
2. Faktor sosial, atara lain: (a) Peningkatan urbanisasi dan industrialisasi akan lebih meningkatkan rekreasi; (b) Peningkatan permintaan akan pemanfaatan waktu senggang melalui iklan; dan (c) Kenaikan bahan bakar mempengaruhi jumlah wisatawan untuk berekreasi.

3. Faktor kebijaksanaan, antara lain: (a) Mengurangai pengangguran melalui penciptaan lapangan kerja; dan (b) Mengembangkan dan menghidupkan daerah tertentu untuk pariwisata.

Proses perubahannya menyangkut peningkatan daya guna sumber daya manusia, sumber daya alam dan teknologi. Interaksi ketiga faktor ini dalam proses perkembangannya tercermin pada pertumbuhan ekonomi dan pertumbuhan penduduk yang pada gilirannya akan mempengaruhi pendapatan masyarakat, lapangan kerja, taraf hidup, ekologi dan tata lingkungan.

\section{Metode Penelitian}

Penelitian ini menggambarkan, meringkas berbagai kondisi situasi, atau berbagai fenomena realitas sosial yang ada dalam masyarakat. Tujuan dari penelitian deskriptif kualitatif ini ditujukan untuk mendeskripsikan atau menggambarkan fenomena-fenomena yang ada di lapangan seperti bentuk, aktivitas, karakteristik, perubahan, hubungan, kesamaan dan perbedaan fenomena sehingga dalam penelitian ini tidak dilakukan manipulasi hanya menggambarkan sesuai kenyataan atau suatu kondisi apa adanya.

Pendekatan kualitatif ini menggunakan tipe kualitatif Menurut Creswell (2010) mengatakan bahwa: "Studi kasus adalah strategi kualitatif dimana peneliti mengkaji sebuah program, kejadian, aktivitas, proses, atau satu atau lebih individu dan aktivitas, sehingga peneliti harus mengumpulkan informasi yang detail dengan menggunakan beragam prosedur pengumpulan data selama periode waktu tertentu".

\section{Hasil dan Pembahasan}

\section{Kondisi Fisik Koridor Jalan Cigondewah Kota Bandung Aksesibilitas \& Jarak antar bangunan di Jalan Cigondewah}

Koridor jalan Cigondewah mempunyai tiga akses masuk kedalam kawasan tersebut. Gerbang pintu kawasan Cigondewah berada tepat sebelum node persimpangan jalan Cigondewah yang merupakan sebagai titik simpul perempatan jalan. Volume kendaraan rata-rata adalah $\pm 80-100$ kendaraan/Jam. Berdasarkan kelas jalan sirkulasi kawasan berupa jalan skunder, jalan lingkungan dan jalan gang. Jaringan jalan yang termasuk jalan skunder adalah jalan Cigondewah Rahayu, jalan Cigondewah Hilir, dan jalan Cigondewah Kaler, Jaringan Jalan tersebut berupa jalan dengan perkerasan aspal dengan lebar sekitar 6-7 meter yang dilalui dua jalur aksesibilitasnya yang pada jam sibuk banyak kendaraan yang dapat menimbulkan kemacetan. Kawasan Cigondewah dilalui oleh angkutan umum yang lalu lalang. 


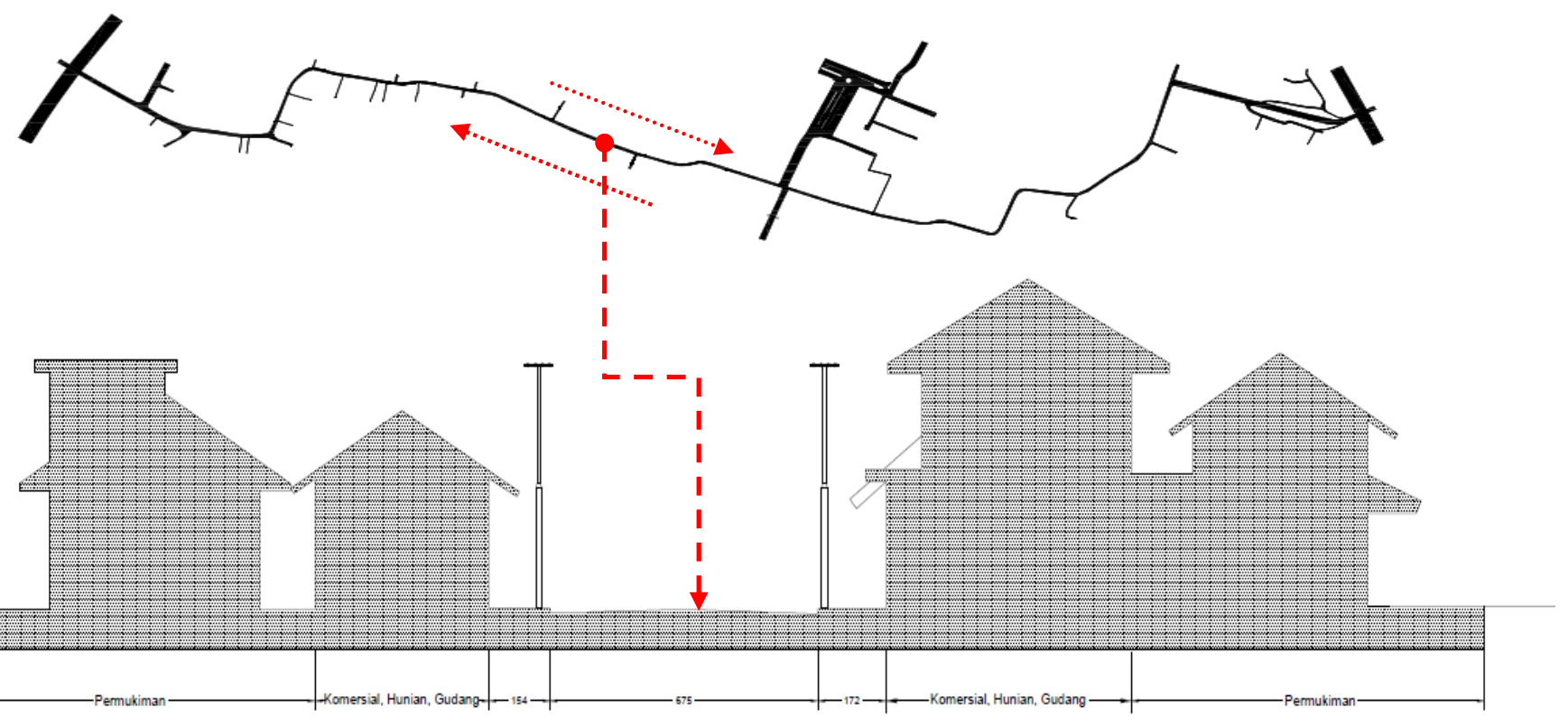

Gambar 1. Potongan eksisting Koridor Jalan Cigondewah

Sumber: Dokumentasi, 2017
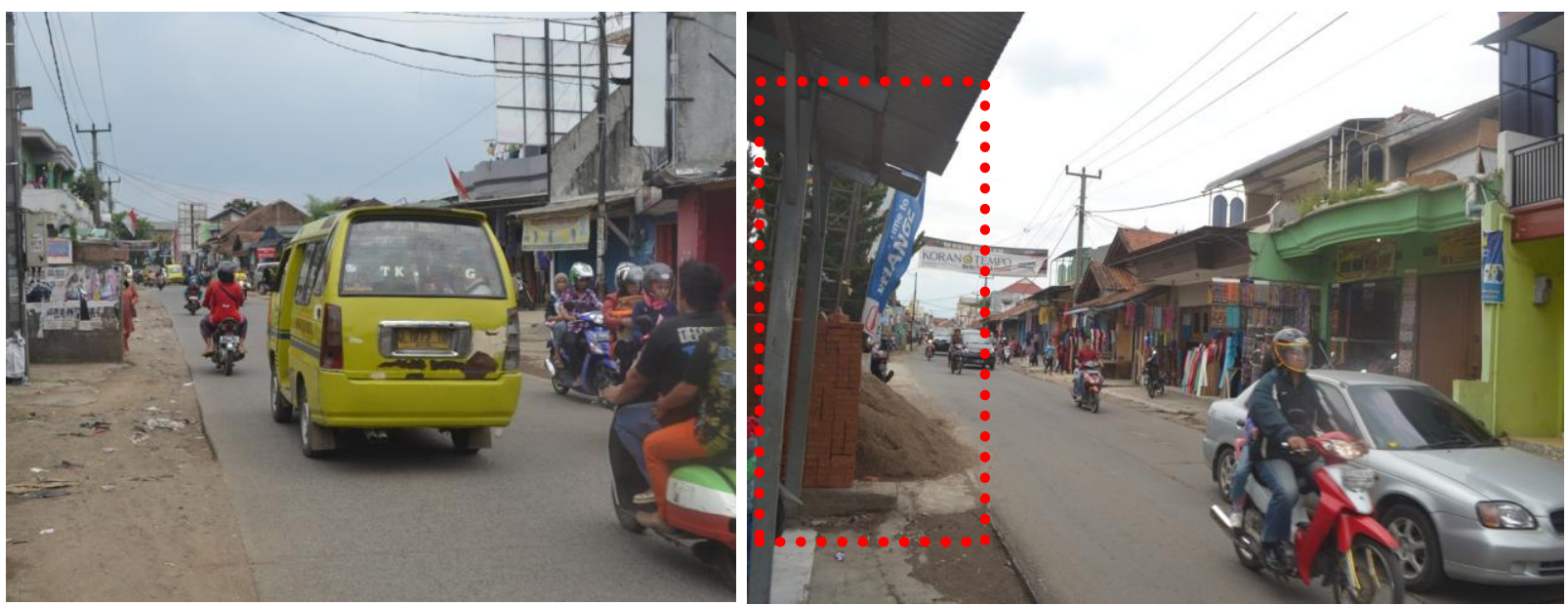

Gambar 2. Kondisi Sirkulasi utama Kawasan Cigondewah Sumber: Dokumentasi, 2017

Sedangkan jaringan jalan yang termasuk kedalam kelas jalan lingkungan adalah berupa jalan aspal selebar 3,5 meter yang berada di lingkungan kawasan Cigondewah yang berfungsi untuk akses ke dalam permukiman jalan Cigondewah. Pada umumnya untuk gang pada kawasan Cigondewah memiliki lebar sekitar 2 meter - 2,5 meter dan sebagian besar hanya dapat dilalui oleh pengendara sepeda motor, pesepeda, dan pejalan kaki. Selain itu juga terdapat beberapa jalan yang merupakan akses milik kelompok kumpulan kios yang berada kedalam membentuk claster pertokoan sepert perumahan akan tetapi semuanya komplek perkiosan yang menjual kain.

Kependudukan Cigondewah sendiri terbilang cukup padat perkembangannya kawasan ini tumbuh sebagai kawasan perdagangan dan industri. Bangunan di sepanjang koridor jalan utama mengalami banyak perubahan fungsi lingkungan binaan. Kondisi dan permasalahan umum koridor Jalan Cigondewah lebih kepada penggunaan ruang kawasan permukiman yang berkembang untuk kegiatan komersial pada bangunan huniannya. Oleh karena itu banyak bangunan yang beralih fungsi tidak sesuai dengan peruntukan lahannya. Perkembangnya Jalan Cigondewah berubah fungsi peruntukan ruangnya sebagai kawasan campuran yaitu perdagangan, jasa, permukiman, dan industri. 
Bangunan di koridor jalan kawasan Cigondewah sendiri memiliki karakter bangunan yang tidak terencana dan terkesan sangat natural.

Bangunan yang ada di sekitaran jalan Cigondewah mempunyai masa bangunan yang tidak tertata dan cenderung tumbuh linier memanjang sepajang jalan Cigondewah. Jalan Cigondewah mengalami perubahan menjadi kawasan wisata tekstil karena letak kawasan ini sangat setrategis dan dekat dengan industri tekstil di sekitar Kota Bandung.Kondisi permukiman sebagian besar tidak tertata dengan baik dengan kondisi sedang sampai baik. Ketinggian lantai bangunan cukup beragam antara satu sampai dua lantai. Sedangkan koifisien dasar bangunan antara 70-90\% dan GSB antara 02 meter. Sedangkan pola penyebaran permukiman di sekitar kawasan perencanaan bersifat linier dengan mengikuti pola jaringan jalan.

\section{Potensi Kawasan}

Jalan Cigondewah Kota Bandung merupakan bagian dari Kec. Bandung Kidul sebagai penyambung antara jalan Holis dengan Jalan Kopo Kota Bandung, lebar jalan Cigondewah adalah \pm 8 meter, radius \pm 1.273 meter, dan luas \pm 10.184 . Jalan Cigondewah sebagai koridor utama di kawasan wisata tekstil Cigondewah Kota Bandung, dimana terdapat bangunan-bangunan hunian yang sebagian ruangnya dijadikan Komersial, Gudang dan di revitalisasi berubah menjadi kios-kios, dan menjadi salah satu kawasan ekonomi kreatif. Kawasan Cigondewah ini digolongkan ke dalam Corridor Open Space yaitu yang berbentuk ruang terbuka yang mempunyai fungsi untuk pergerakan dan transportasi sebagai mobilitas Kota. Corridor Open Space berfungsi sebagai akses publik atau fasilitas umum, dimana karakter koridor dapat terbentuk dari perbandingan elemen pembentuknya serta perbandingan dengan sekala manusia.

Konsep wisata belanja seperti di atas dapat pula diterapkan pada sentra industry dan penjualan kain di Cigondewah. Industri kain Cigondewah sendiri merupakan salah satu mata rantai perdagangan kawasan yang cukup mendominasi aktivitas masyarakat setempat. Hal ini yang mengakibatkan tumbuhnya fungsi industri di tengah-tengah fungsi hunian di kawasan ini. Fungsi industri ini tidak hanya meliputi fungsi produksi saja tetapi juga termasuk penjualan produk grosir dan retail. Penanganan terhadap fungsi ini dapat dilakukan dapat membatasi jumlah rumah yang meliputi industri di dalamnya, menyediakan satu area khusus sebagai tempat produksi, dan memisahkan antara bangunan untuk produksi dengan tempat berjualan terpusat. Bangunan produksi dan bangunan sebaiknya di satu area agar tidak menyulitkan proses produksi secara keseluruhan.

\section{Isu Masalah Lingkungan}

Permasalahan kawasan permukiman padat Cigondewah akan ditingkatkan kualitas lingkungannya melalui pendekatan peningkatan kualitas prasaranan dan pemberdayaan potensi ekonomi yang ada didalamnya. Pada kondisi saat ini dengan prasarana dasar yang masih kurang layak namun roda perputaran ekonomi dikawasan Cigondewah terbilang positif. Diharapkan dengan adanya peningkatan kualitas prasarana dapat membantu meningkatkan tingkat produktifitas ekonomi lainnya.

Masyarakat kawasan Cigondewah membutuhkan dukungan guna meningkatkan kepedulian terhadap lingkungannya. Minimnya kepedulian masyarakat dan kurang kuatnya daya dukung pemerintah membuat lingkungan kawasan Cigondewah kehilangan keasriannya. Masyarakat sering tidak menyadari, kehidupan mereka sebenarnya terancam. Tak hanya sisi ekonomi atau lingkungan,tapi juga identitas diri.

Dengan alasan ekonomi, tidak terhitung lagi banyaknya daerah yang keberadaannya terancam, terutama lingkungan tempat tinggal. Hal ini sangat berbahaya karena berpotensi mengubah prilaku dan kehidupan sosial masyarakat.

Kawasan industri Cigondewah selayaknya harus memiliki tempat pembuangan sampah dan pengelolaan limbah tersendiri. Kondisi eksisting menunjukkan, kawasan tidak mempunyai tempat pengolahan khusus, lahan kosong menjadi sarana utama pembuanagn sampah. Hal tersebut dapat 
menurunkan kualitas lingkungan dan berpengaruh kepada kondisi fisik masyarakat penghuninya. Drainase yang ada di koridor Cigondewah berada di sisi kiri-kanan jalan, tetapi tidak semua jalan mempunyai drainase. Drainase existing sekarang kondisinya masih tidak bagus. Lebar dan kedalaman drainase hanya sekitar $\pm 0,5 \mathrm{~m}$. Drainase ini ada yang tertutup dan ada yang terbuka. Drainase ini perlu direncanakan di buat kembali dengan lebih baik.

Ruang terbuka yang terdapat di koridor cigondewah berupa lapangan sepak bola, pemakaman umum, dan lahan kosong yang belum dimanfaatkan. Keadaan lahan-lahan kosong yang berfungsi sebagai lahan pertaniaan, dapat di jadikan salah satu potensi view maupun fungsional, sebagai daerah penghijauan dalam kawasan. Ruang-ruang hijau tersebut dapat dijadikan penghubung antar kawasan sehingga menciptakan keterkaitan visual, untuk lebih memperkuat karaktur wisata yang ingin ditonjolkan di kawasan ini. Untuk membentuk keterkaitan visual tersebut dibutuhkan suatu sekenario yang akan menghasilkan suasana yang menarik dan berada saling memiliki keterkaitan.

\section{Analisis}

\section{Kesadaraan Masyarakat dengan Lingkungannya}

Masyarakat sendiri belum sepenuhnya sadar akan manfaat dari menjaga lingkungan area wisata kain Cigondewah. Oleh karena itu banyak para pengunjung yang menilai bahwa Cigondewah sering tergenang banjir saat mereka berbelanja. Buruknya sistem transportasi sepanjang jalan menuju kios yang satu dengan yang lainnya juga menjadi kendala.

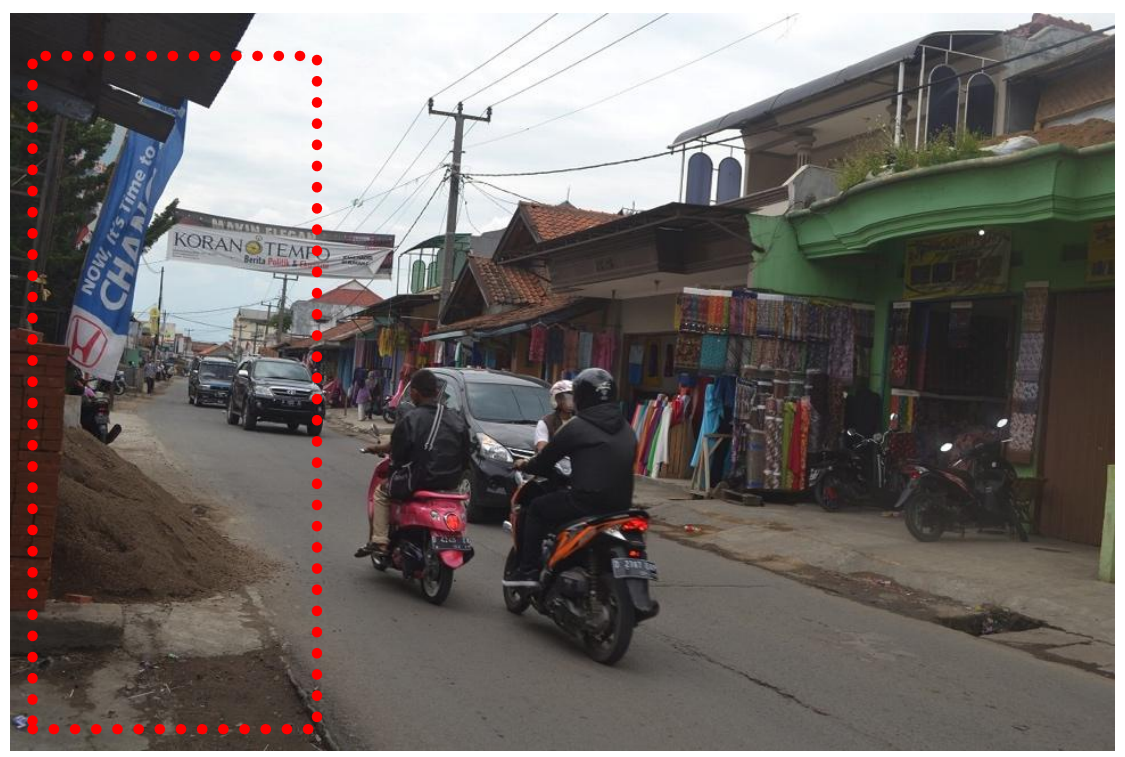

Gambar 3. Kondisi Jalan di sepanjang Cigondewah.

Sumber: Dokumentasi, 2017

Dari gambar 1 terlihat jelas jalur pedestrian yang belum ada di sekitar sepanjang jalan ini sehingga masih tidak mempedulikan akan kesadaran masyarakat terhadap pengunjung atau wisatawan pembeli kain di tempat ini. Tumpukan pasir yang menghalangi jalur pedestrian makin memperparah tingkat kesadaran masyarakat akan bahaya yang ditimbulkannya. 


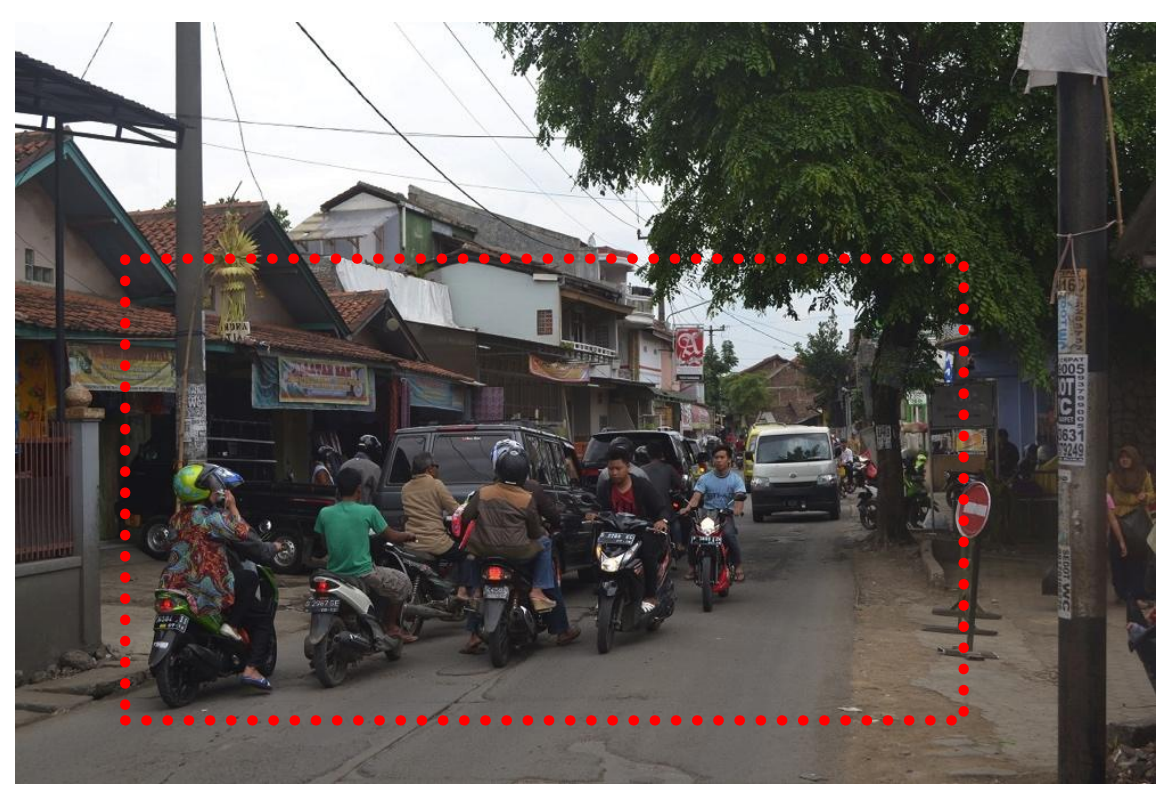

Gambar 4. Kondisi Jalan di sepanjang Cigondewah.

Sumber: Dokumentasi, 2017

Suasana transportasi yang sedikit padat pada jam-jam sibuk biasanya menimbulkan beberapa titik kemacetan sehingga suasana jalan menuju lokasi sedikit tersendat. Terlihat beberapa pengendara motor yang tidak tertib ikut memperparah suasana padatnya akses menuju lokasi. Para pengunjung yang datang kelokasi juga merasa tidak nyaman dengan kondisi jalan yang padat.

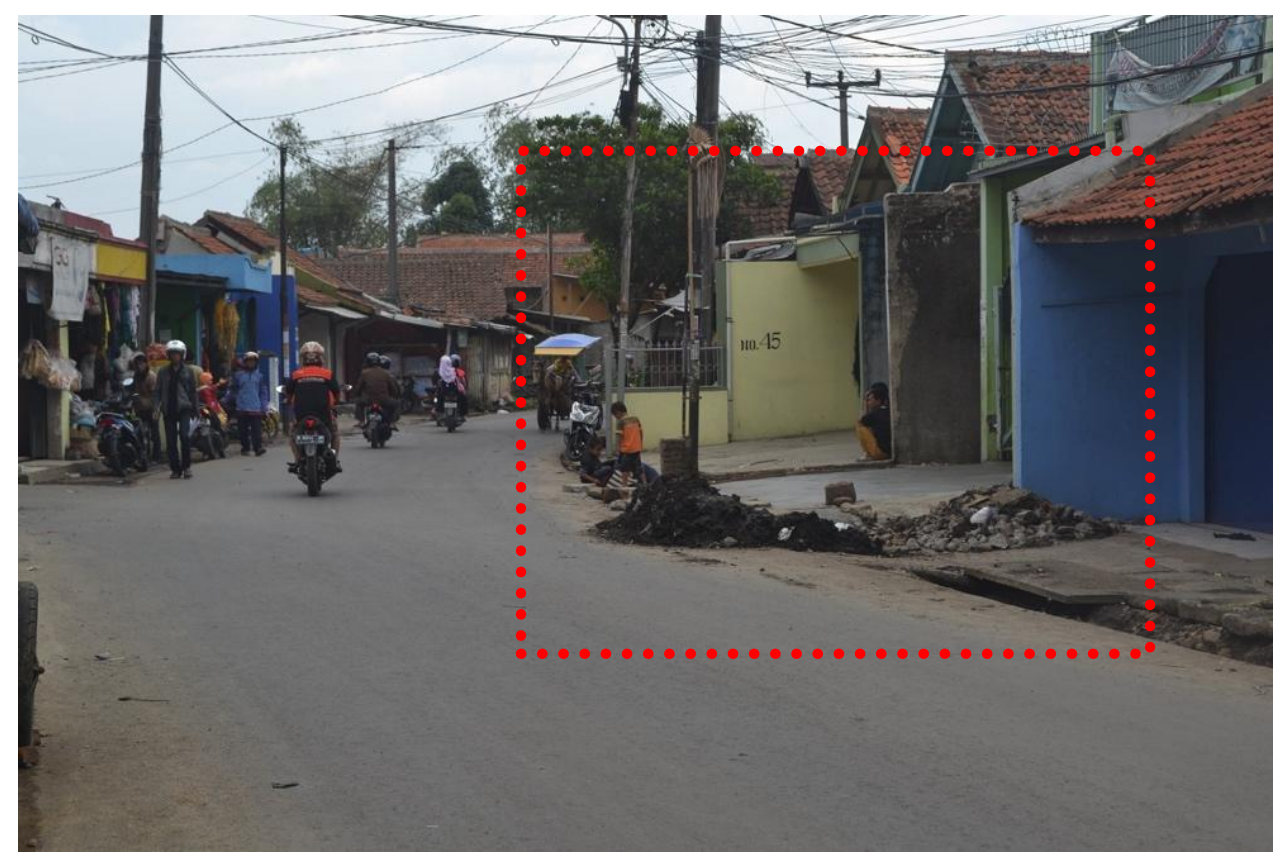

Gambar 5. Perbaikan saluran drainase di jalan Cigondewah. Sumber: Dokumentasi, 2017

Saluran drainase sering mengakibatkan genangan di badan jalan ini merupakan akibat dari ketidak sadaran warga yang tidak tertib membuang sampah sembaranga. Terlihat tumpukan sampah yang diangkat dari saluran drainase ini begitu banyak, sehingga pemandangan ini menimbulkan akan image yang buruk pada sarana dan prasarana jalan di kawasan wisata Cigondewah tersebut. Di sepanjang jalan ini juga tidak disediakannya sarana parkir motor sehingga motor berseserakan di 
sembarangan tempat. Hal ini di keluhkan khususnya bagi para pengunjung yang mampir di kios-kios di sepanjang jalan.

\section{Partisipasi Masyarakat untuk mengelola limbah}

Begitu banyaknya dampak dari kawasan wisata kain di Cigondewah diantaranya limbah bekas gulungan kain yang begitu menumpuk sehingga sebagian warga menadikan sampah-sampah gulungan itu dikumpulkannya untuk di olah kembali. Warga yang mengumpulkan sampah bekas gulungan kain itu sendiri di jadikan sebagai mata pencahariannya di tengah-tengah penduduk yang sebagian besar sebagai penjual kain baik kain kiloaan maupun meteran.

Limbah-limbah bekas gulungan kain ini di kumpulkan di lokasi tidak jauh dari kawasan wisata belanja kain tersebut. Akan tetapi limbah ini di tempatkan pada zona di sudut dekat kawasan pabrik yang menyumbang juga dampak lingkungan yaitu memperburuk sebagian wilayah tersebut.

Salah satu partisipasi masyarakat yang mengumpulkan sisa limbah dari aktivitas kawasan wisata kain di Cigondewah juga mempunyai andil dalam menyumbang kerusakan lingkungan tersebut. Dari pengamatan peneliti terlihat beberapa gudang yang tidak tertata sehingga limbah yang mereka kumpulkan berantakan. Sehingga sebagian sisanya dibuang kesungai di samping lokasi gudang. Hal ini merupakan begitu buruknya pengelolaan lingkungan ini diakibatkan warga sekitar Cigondewah hanya mementingkan aspek ekonominya saja yang mereka utamakan ketimbang berperan juga memelihara lingkungannya.

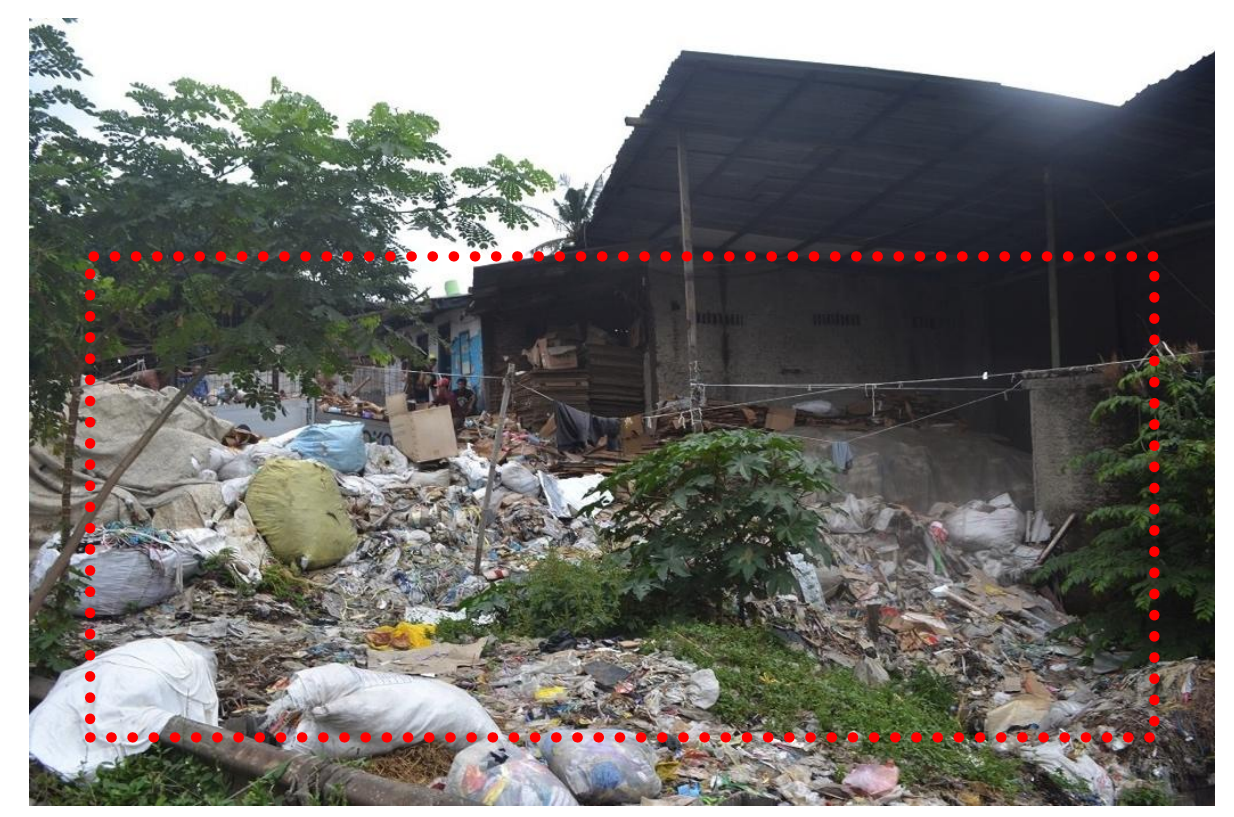

Gambar 6. Suasana Gudang limbah bekas Plastik dan potongan kain. Sumber: Dokumentasi, 2017

Dari hasil pengamatan lingkungan terlihat jelas kurangnya kesadaran sebagian warga untuk menjaga lingkungan kawasan wisata kain Cigondewah membuat sebagian wisatawan merasa perihatin akan hal tersebut, mengingat potensi yang di miliki Cigondewah adalah sungguh luar biasa, untuk menopang perekonomian warga sekitar kawasan.

\section{Kesimpulan}

Perkembangan kawasan ini memberikan potensi yang luas terutama dalam pengembanganya sebagai sebuah kawasan yang memiliki produk unggulan atau spesialisasi dalam cakupan rencana pengembangan pariwisata Kota Bandung. 
Sumber daya manusia yang menjadi tenaga kerja pada kawasan ini umumnya masih berpendidikan umum, sehingga belum mempunyai kualitas yang handal, baik secara administrasi maupun teknis. Fasilitas prasarana dan sarana pendukung kawasan belum memadai seperti jalan yang hanya dua jalur, tidak ada areal parkir dan trotoar serta sistem drainase yang masih buruk sehingga hal-hal tersebut menjadikan kawasan ini tidak terlalu nyaman bagi pengunjung yang memiliki tujuan untuk berwisata.

Dari potensi yang dikemukakan di atas masih banyak masalah sarana dan prasarana yang belum mendukung diantaranya adalah:

1) Belum tersedianya lahan parkir bagi pengunjung atau wisatawan yang akan datang untuk berbelanja terutama pada kios yang tepat berada di sepanjang jalan cigondewah. Sehingga pengunjun belum tertib dalam memarkir kendaraannya dan mengakibatkan terganggunya pengguna jalan yang mau melewati jalan Cigondewah.

2) Belum tersedianya area pejalan kaki yang memadai sehingga wisatawan atau pengunjung ennggan berjalan di sepanjang jalur pedestrian.

3) Buruknya drainase sepanjang jalan cigondewah hal ini mengakibatnya ada beberapa titik genangan di sepanjang jalan cigondewah sehingga wisatawan yang berkunjung ke lokasi tersebut memberikan image kawasan ini adalah kawasan kumuh.

4) Lokasi penempatan gudang limbah baik limbah plastik, limbah gulungan bekas kain serta potongan sisa kain semua limbah tersebut masih belum terolah dengan maksimal.

Kurangnya kesadaran sebagian warga untuk menjaga lingkungan kawasan wisata kain Cigondewah membuat sebagian wisatawan merasa perihatin akan hal tersebut, mengingat potensi yang di miliki Cigondewah adalah sungguh luar biasa, untuk menopang perekonomian warga sekitar kawasan.

\section{Daftar Pustaka}

Creswell, J. W. (2010). Research Design: Pendekatan Kualitatif, Kuantitatif, dan Mired. Yogyakarta: Pustaka Pelajar.

Hadi, S. P. (2001). Manusia dan Lingkungan. Semarang: Badan Penerbit Universitas Diponegoro.

Jaya, I. (2007). Pengelolaan Lingkungan Kawasan Wisata Danau Lebo Kecamatan Taliwang Kabupaten Sumbawa Barat. Universitas Diponegoro.

Sudjarto, D. (1985). Diktat Kuliah Perencanaan Kota Baru. Bandung: ITB.
Sugandhy, A. (1999). Penataan Ruang dalam Pengelolaan Lingkungan hidup. Jakarta: PT. Gramedia Pustaka Utama.

Undang-undang No. 9 tahun 1990. (1990). Undangundang Republik Indonesia Nomo 9 tahun 1990.

Wijaya, K., Setioko, B., \& Murtini, T. W. (2015). Pengaruh Perubahan Fungsi Lingkungan Binaan terhadap Citra Kawasan Wisata Tekstil Cigondewah Kota Bandung. Jurnal Arsitektur Komposisi, 11(2), 67-75. Retrieved from ojs.uay.ac.id 